\title{
Placenta Growth Factor Isoform 1
}

National Cancer Institute

\section{Source}

National Cancer Institute. Placenta Growth Factor Isoform 1. NCI Thesaurus. Code

C126117.

Placenta growth factor isoform 1 (149 aa, $\sim 17 \mathrm{kDa}$ ) is encoded by the human PGF gene.

This protein may be involved in the positive regulation of endothelial cell growth. 